Research Article

\title{
Concentrating Mill Wastes are the Source of Pollution of Human Environment and Natural Ecosystems with Heavy Metals: A Case Study in Primorsky Krai, Russian Federation
}

\author{
Irina A. Tarasenko, ${ }^{1,2}$ Alexander V. Zin'kov, ${ }^{2}$ Aleksei S. Kholodov ${ }^{D},{ }^{1}$ Muhammad Riaz, ${ }^{3}$ \\ Valeriy I. Petukhov, ${ }^{2}$ Nikita Y. Popov, ${ }^{1}$ Aristidis Tsatsakis, ${ }^{4}$ and Kirill S. Golokhvast $\mathbb{D}^{2,5}$ \\ ${ }^{1}$ Far East Geological Institute of the Far Eastern Branch of the Russian Academy of Sciences, Vladivostok 690022, Russia \\ ${ }^{2}$ Far Eastern Federal University, Vladivostok 690950, Russia \\ ${ }^{3}$ Department of Environmental Sciences and Engineering, Government College University, Faisalabad 38000, Pakistan \\ ${ }^{4}$ School of Medicine, University of Crete, Heraklion 71003, Greece \\ ${ }^{5}$ Pacific Geographical Institute of the Far Eastern Branch of the Russian Academy of Sciences, Vladivostok 690041, Russia
}

Correspondence should be addressed to Aleksei S. Kholodov; alex.holodov@gmail.com

Received 13 November 2019; Revised 6 March 2020; Accepted 9 May 2020; Published 1 June 2020

Academic Editor: James Barker

Copyright (c) 2020 Irina A. Tarasenko et al. This is an open access article distributed under the Creative Commons Attribution License, which permits unrestricted use, distribution, and reproduction in any medium, provided the original work is properly cited.

\begin{abstract}
Elevated contents of hazardous elements in natural ecosystems are often associated with human activities. Significant quantities of these elements, including heavy metals, are concentrated in tailings. The goal of the study was to assess the mineralogical and geochemical features of the old tailings of the decommissioned Krasnorechenskaya concentrating mill (located in Primorsky Krai, Russian Federation), which was processing complex tin-polymetallic and silver-lead-zinc ores, the chemical features of tailings pond waters, and the extent of environmental impact on the nearby Rudnaya river. In addition to the analysis of rock and water samples, the software modeling of the water-rock-gas system was carried out. In the study area, the minerals and rocks undergo changes that lead to the formation of highly mineralized, acidic waters saturated with various elements. In the tailings ponds, the maximum permissible concentrations were exceeded for $\mathrm{Zn}, \mathrm{Cd}, \mathrm{Cu}, \mathrm{Mg}, \mathrm{Fe}_{\text {total }}, \mathrm{Pb}, \mathrm{Mn}, \mathrm{Al}, \mathrm{As}, \mathrm{Co}, \mathrm{Be}, \mathrm{Sr}, \mathrm{Ni}$, and $\mathrm{Ba}$. The drainage from the tailings pond tripled the total mineralization of the Rudnaya river relative to the background values. However, the intoxication of the ecosystem by tailing products is partially inhibited by the secondary minerals in the tailings ponds. The negative impact is of a local nature, and $500 \mathrm{~m}$ downstream the concentration of many of the above elements is reduced. Despite this, the system that forms the chemical composition of highly mineralized waters is far from the equilibrium state. The oxidation of sulfides, dissolution of other minerals, and migration of oxidation and hydrolysis products will continue affecting the environment. In this regard, it is necessary to conduct environmental monitoring and undertake activities aimed at the recovery of mature concentration tailings or at suppressing the activity of hazardous elements by the conservation of tailings ponds.
\end{abstract}

\section{Introduction}

Tailings are a source of high concentrations of heavy metals, harmful elements, and substances accumulated in significant quantities in tailings. This is a serious issue for many mining regions widely discussed by the researchers [1-21]. Sulfides in oxidized leach cap that are not extracted during the enrichment are intensively acidified. As a result, the oxidation products of ore minerals become mobile. This leads to acid rock drainage with elevated contents of heavy metals fundamentally different from the waters in the region. The specific composition of acid drainage may cause the destruction of hydrobiocenosis in watercourses impacting their self-purification ability [22-30].

Therefore, the task of reliable assessment of the impact of acid rock drainage on the human environment and natural ecosystems through chemical and mineralogical analyzes is particularly relevant $[31,32]$. 
The technology of processing of ore in Russian Federation has not been perfect for a long time $[4,33,34]$. The extraction ratio of base metals into lead and zinc concentrates was $92-98 \%$ for galena and sphalerite and $80-85 \%$ for silver. The remainder together with other metallic sulfides was discharged into pulp consisting of up to $87 \%$ of nonmetallic minerals. About $10 \%$ of silver, $2-8 \%$ of lead in galenic form, and $1-5 \%$ of zinc in sphalerite form were discharged into tailings. Incorporated into magnetite, pyrrhotite, pyrite and marcasite, $56.3 \%$ to $93.8 \%$ of iron, $66-98 \%$ of arsenic, $10-15 \%$ of antimony, and $38-46 \%$ of silicon earth in the form of quartz, hedenbergite, and other silicates were discharged into tailings, as well as Se, Te, In, $\mathrm{Ge}, \mathrm{Tl}, \mathrm{Ga}$, and $\mathrm{F}[4]$.

The tailings ponds of the Krasnorechenskaya concentrating mill (KCM) have been filled for 40 years (from 1956 to 1995), and now they contain more than 6.8 million tons of waste, with large amounts of sulfides. These wastes act as potentially toxic metal sources to the surrounding ecosystem and residential areas [4]. The migration of metals offsite is primarily through airborne dispersion of fine particles and waterborne transport of dissolved and particulate metals [35]. Various geochemical characteristics of the tailings, specifically solid-phase speciation, particulate size, and metal concentrations, determine the potential for the metals to migrate offsite and expose humans and animals to potentially toxic metal concentrations [36-38].

The mineralogical and geochemical features of mature concentration tailings, the chemical composition of the water in the tailings ponds, and the scale of the environmental impact of the tailings drainage on the Rudnaya river are discussed in this paper. To achieve this, we used the concentration tailings of KCM accumulated in the "old" and "new" tailings ponds as the study material.

\section{Materials and Methods}

2.1. Study Area. The KCM and its tailings ponds are located in the Dalnegorsky district of the Primorsky Krai, Russian Federation (Figure 1). During the operation period (1956-1995), the mill was processing complex tin-polymetallic and silver-lead-zinc ores from the Smirnovskoe and Yuzhnoe deposits. The minor valuable components were silver, antimony, cadmium, bismuth, copper, and indium [39-42].

2.2. Sample Collection and Analysis. The samples were collected from the surface of the mature tailings ponds of KCM and through sinking the pits $2.0-2.5 \mathrm{~m}$ deep with a scoop. In addition, we used the results of our earlier geochemical sampling of five holes set on an optimally predetermined network by the five-spot pattern at the depth of 10-15 $\mathrm{m}$. The distance between the holes was 100 and $150 \mathrm{~m}$.

The samples for geochemical, mineralogical, and hydrochemical analyzes were collected in 2015. Geochemical samples were collected by the vertical channel method in each visually distinguished layer with the greatest variability in composition and structure of the mature tailings. The

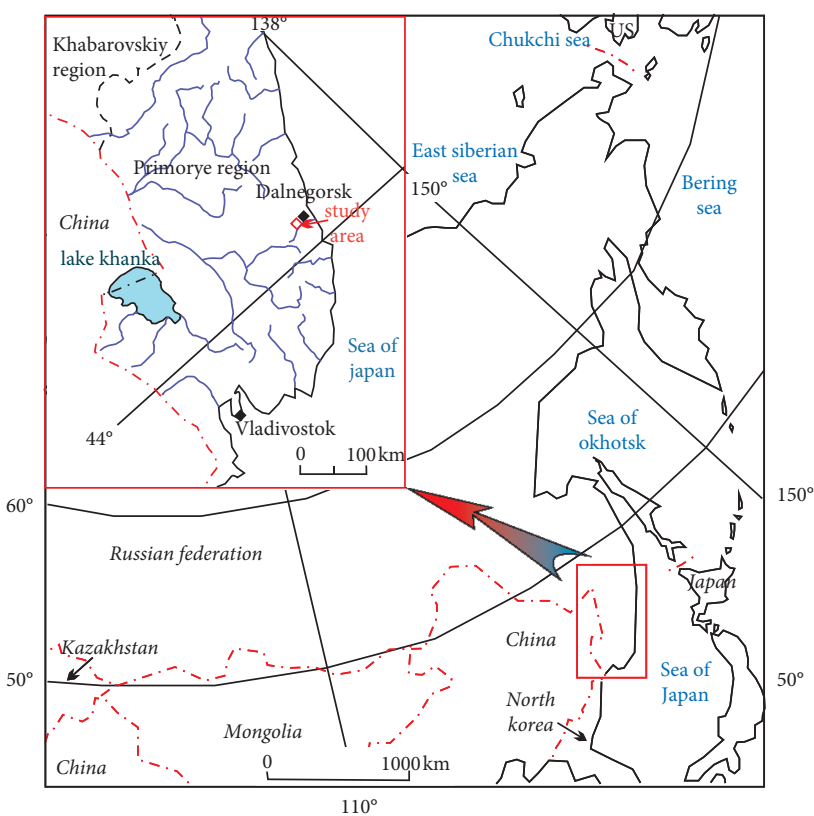

Figure 1: The location of the study area.

mineralogical samples were collected by pit sampling method into the sealed glass sample bottles. The samples for hydrochemical analysis were collected in the tailings ponds and in the Rudnaya river, which receives the drainage. The samples in the river were taken directly at the site of the drainage spontaneous discharge, above the discharge $(1 \mathrm{~km})$ and below the discharge $(0.5 \mathrm{~km})$, according to the Russian sampling standard GOST 17.1.5.04-80 [43].

Hydrochemical samples for the analysis of cations and sulfates were filtered through a $0.45 \mu \mathrm{m}$ filter at the sampling site and acidulated with nitric acid. For detection of anions, the samples were also filtered and collected in polyethylene containers without acidulation. Unstable parameters were measured at the sampling site.

The laboratory analytical studies were carried out at the Analytical Center of the Far East Geological Institute FEB RAS. The contents of elements in the samples were detected by mass spectrometry with inductively coupled plasma using the Agilent $7700 \mathrm{C}$ spectrometer (Agilent Technologies, USA) and atomic-emission spectrometry with inductively coupled plasma using the iCAP 6500Duo spectrometer (Thermo Scientific Corporation, USA). The contents of $\mathrm{H}_{2} \mathrm{O}^{-}$, losses on ignition, and $\mathrm{SiO}_{2}$ were determined by gravimetric analysis. The sample preparation of solid samples for instrumental analysis consisted of open acid decomposition $\left(\mathrm{HNO}_{3}+\mathrm{HClO}_{4}+\mathrm{HF}\right)$ according to the Russian certified method NSAM No. 499-AES/MS [44].

Mineralogical studies were performed by X-ray spectral microanalysis using the INCA-sight energy dispersive spectrometer (Oxford Instruments, $\mathrm{UK}$ ) and $\mathrm{X}$-ray analysis using the DRON-3 diffractometer with monochromatic radiation and the D8-Discover microdiffractometer. The micromorphology and the composition of the mineral phases were studied using the scanning electron microscopes JSM-6490LV and ZEISS EVO 50XVP equipped with 
X-ray energy-dispersive INCA energy spectrometers, in secondary and reflected electron modes with the accelerating voltage of 20 kilovolt and beam currents $n \bullet 10^{-12}$, and also using the Nikon Eclipse LV100 Pol light microscope.

To determine the patterns of hydrogeochemical processes in tailings and possible stable transformations of minerals and their assemblages, we modeled the water-rockgas system using the software package "Selektor" (๔ 2007 by $\mathrm{K}$. V. Chudnenko), which is based on minimizing the isobaric-isothermal potential (or Gibbs potential) [45]. The modeling technique consisted of a series of calculations of the equilibrium state for the water-rock-gas system. The external conditions of the system (temperature, total pressure, and chemical potentials of each boundary value component) were entered into the software. The reliability of the results of the equilibrium-nonequilibrium state calculations was determined by using the actual ion concentrations rather than gross masses of the chemical components. The natural chemical composition of the rocks composing the tailings was calculated based on the number of moles of each component and entered into the software. A set of phases and forms of chemical elements in the modeled system was compiled. The model of the water-rock-gas system was represented as a matrix of 57 dependent components and 392 independent components, including 347 aqueous phase components, 37 mineral phase components, and 8 gaseous phase components. We used the thermodynamic properties of minerals, gases, and aqueous solution components from the following databases (adapted to the Selektor software package): a_Shock [46-51], g_Reid [52], s_dump, s_Robie Hemingway [53], and s_Yokokawa [54]. The model simulated the dissolution of rocks in a closed system $\left(\mathrm{CO}_{2}\right.$ was $0.01 \mathrm{~kg} / \mathrm{L}$ per $1 \mathrm{~kg}$ of $\mathrm{H}_{2} \mathrm{O}$, and the atmospheric gas was $0.3 \mathrm{~kg} / \mathrm{L}$ per $1 \mathrm{~kg}$ of $\mathrm{H}_{2} \mathrm{O}$ ). The equivalence of the models to real natural objects was assessed by the correspondence of the calculated ratios of chemical elements in the waters, $\mathrm{pH}$ of the medium, and mineralogical composition of the newly formed solid phases to the natural parameters.

\section{Results and Discussion}

3.1. Mineralogical Composition. The concentration tailings are represented by a mixture of mineral particles of different sizes: from a fraction of a micron to $3 \mathrm{~mm}$. According to the particle composition, they are characterized by the presence of coarse-grained sandy variations $(+0.4 \mathrm{~mm})-2 \%$, medium-sized soils $(-0.4 \ldots+0.2 \mathrm{~mm})-10 \%$, small-sized soils $(-0.2, \ldots, \quad+0.07 \mathrm{~mm})-36 \%$, and silty variations $(-0.7 \mathrm{~mm})-52 \%$, which are cemented together with hydroxide-ferruginous, clay-limonite, and sulfate monocrystalline material [4]. The aggregate concentrations of phlogopite type hydromica sized up to $0.3 \mathrm{~mm}$, often associated with the chlorite-like substance, are found in the cement [4].

The total sum of sulfides in the mature concentration tailings of KCM ranges from 5 to $35 \%$ (Figure 2), where $80 \%$ are pyrite and marcasite, $15 \%$ sphalerite and galena, and about $4-5 \%$ pyrrhotite, chalcopyrite, stannite, and arsenopyrite. There are grains of silver minerals represented by argentite, hessite, and sulphosalts of pearceite-polybasite order, which are deposited in the form of emulsion spots in galena, jamsonite, and less often in pyrrhotite and sphalerite [19].

The oxidized ores are typical for the mature tailings. The hypogene galena is transformed into anglesite, cerussite, and plumbojarosite, which is found as a result of mineralogical studies (Figure 2). The oxidized zinc phase is represented by smithsonite and goslarite.

3.2. Chemical Composition. Significant amounts of different elements are accumulated in the tailings of $\mathrm{KCM}$, including $\mathrm{As}, \mathrm{Pb}, \mathrm{Zn}, \mathrm{Cd}, \mathrm{Fe}, \mathrm{Mn}$, and $\mathrm{Sn}$. The content of tin, for example, varies from 170 to $1000 \mathrm{gm} / \mathrm{ton}$, and zinc concentrations amount to $13,920 \mathrm{gm} / \mathrm{ton}$, lead $11,700 \mathrm{gm} / \mathrm{ton}$, arsenic 10,000 gm/ton, and silver $75 \mathrm{gm} /$ ton (Table 1).

As a consequence of the oxidation processes, which are active in the tailings due to the interaction of the minerals that make up the ephemeral sands with the natural waters (precipitation), with the active participation of oxygen, a part of the solid phase blends into the solution. In the "new" tailings pond of KCM, the soft sulfate calcium waters are formed $\left(154.2 \mathrm{mg} / \mathrm{dm}^{3}\right.$ mineralization). The maximum permissible concentrations in the waters are exceeded in $\mathrm{Fe}_{\text {total }}$ (17.7 times), $\mathrm{Zn}$ (42.2 times), and Mn (168.1 times). The content of the remaining components is normal (Table 2).

A different situation is typical for the "old" tailings pond of $\mathrm{KCM}$, where high-mineralized, brackish (6844.6-12807.3 mg/ $\mathrm{dm}^{3}$ mineralization) and acidic $(\mathrm{pH}=2.3-2.5)$ sulfate calcium waters are formed as a result of hypergene transformations with elevated content of $\mathrm{Zn}, \mathrm{Cd}, \mathrm{Cu}, \mathrm{Mg}, \mathrm{Fe}_{\text {total }}, \mathrm{Pb}, \mathrm{Mn}, \mathrm{Al}$, As, $\mathrm{Co}, \mathrm{Be}, \mathrm{Sr}, \mathrm{Ni}$, and $\mathrm{Ba}$ (Table 2).

Zinc is an active water migrant, and in the water of the tailings ponds under study, its concentration reaches $111.6 \mathrm{mg} / \mathrm{dm}^{3}$ (in the "old" tailings pond) at the permissible levels of $0.01 \mathrm{mg} / \mathrm{dm}^{3}$ for river water [56] and $5.0 \mathrm{mg} / \mathrm{dm}^{3}$ for drinking water [57].

The mobility of cadmium is much lower in reducing conditions than in oxidizing ones. The content of $\mathrm{Cd}$ in the water of the "old" tailings pond $(\mathrm{pH}=2.3-2.5)$ is $0.04 \mathrm{mg} /$ $\mathrm{dm}^{3}$ at the permissible levels of $0.005 \mathrm{mg} / \mathrm{dm}^{3}$ [56] and $0.001 \mathrm{mg} / \mathrm{dm}^{3}$ [57]. In the water of the "new" tailings pond $(\mathrm{pH}=7.4)$, the concentration of $\mathrm{Cd}$ does not exceed $0.0012 \mathrm{mg} / \mathrm{dm}^{3}$ (Table 2).

Copper in the oxidized leach cap migrates well in acidic media [58], and apparently due to this characteristic, its content in the water of the "old" tailings pond amounts to $0.27 \mathrm{mg} / \mathrm{dm}^{3}$ at the permissible level of $0.005 \mathrm{mg} / \mathrm{dm}^{3}$.

Nickel fits into the same group with $\mathrm{Zn}, \mathrm{Cd}$, and $\mathrm{Cu}$, which are mobile or poorly mobile in oxidizing and gley environment [58]. In the water under study, its content varies from 0.53 to $0.06 \mathrm{mg} / \mathrm{dm}^{3}$ at the permissible level of $0.01 \mathrm{mg} / \mathrm{dm}^{3}$.

In terms of migration, cobalt differs from nickel. It is mobile in reducing gley environments, but it deposits both on the hydrosulfuric and on the oxidation barriers. This is 

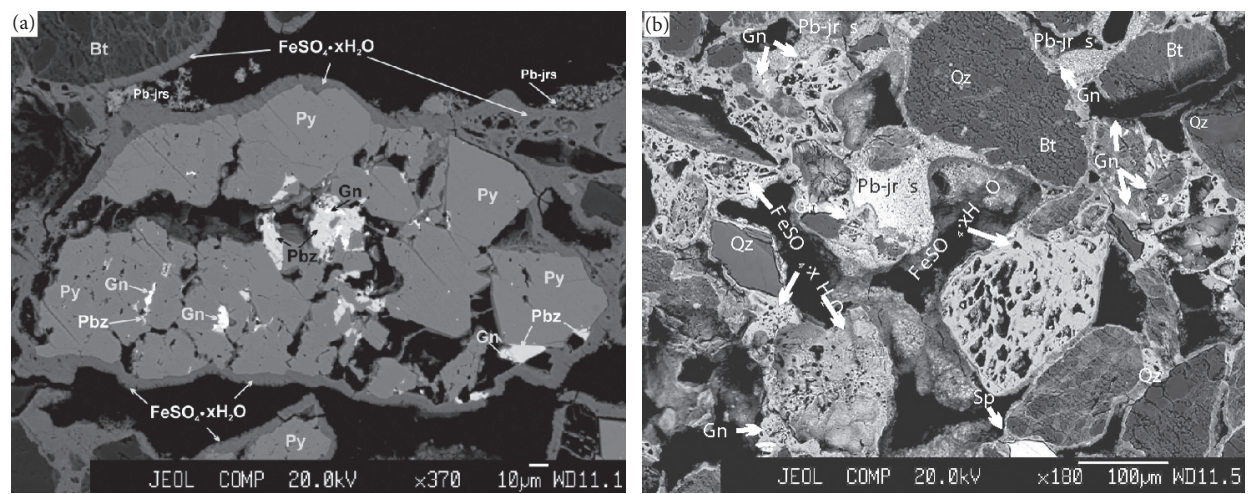

FIGURE 2: The prevailing mineral forms in mature concentration tailings; (a) isometric grains of galena in pyrite metacrystals, eroded pyrite crystal, and new formations of iron sulfates; (b) plumbojarosite and other hypogene and hypergene minerals: Bt, biotite, Gn, galena, Py, pyrite, Qz, quartz, $\mathrm{Sp}$, sphalerite, $\mathrm{Pb}$-jrs, plumbojarosite, and $\mathrm{FeSO}_{4} \mathrm{xH}_{2} \mathrm{O}$ in the form of cementing phases. Photographed using the energydispersive spectrometer INCA-sight (Oxford Instruments, Great Britain).

TABLE 1: The content of elements in the tailings of KCM.

\begin{tabular}{|c|c|c|c|c|c|}
\hline \multirow[t]{2}{*}{ Element } & \multirow[t]{2}{*}{ Clark in the Earth's crust, gm/ton [55] } & \multicolumn{2}{|c|}{$\begin{array}{l}\text { "New" tailings pond, } \\
\mathrm{V}=3.9 \mathrm{mln} t, n=20 \\
\text { Content, gm/ton }\end{array}$} & \multicolumn{2}{|c|}{$\begin{array}{l}\text { "Old" tailings pond, } \mathrm{V}=2.9 \mathrm{mln} t \\
n=86 \\
\text { Content, gm/ton }\end{array}$} \\
\hline & & Range & Mean & Range & Mean \\
\hline $\mathrm{Zn}$ & 93.0 & $700.0-1000.0$ & 905.0 & $300.0-13920.0$ & 3094.2 \\
\hline $\mathrm{Pb}$ & 20.0 & $710.0-1400.0$ & 1071.5 & $680.0-11700.0$ & 2459.9 \\
\hline As & 12.0 & $650.0-2500.0$ & 1027.5 & $400.0-10000.0$ & 2325.0 \\
\hline Sn & 6.4 & $260.0-630.0$ & 389.0 & $170.0-1000.0$ & 531.3 \\
\hline $\mathrm{Fe}$ & 44200.0 & $59082.0-199080.0$ & 108031.0 & $13682.0-460740.0$ & 144989.0 \\
\hline $\mathrm{Al}$ & 77200.0 & $41022.0-62487.0$ & 51417.6 & $6837.0-57028.0$ & 44567.1 \\
\hline $\mathrm{Mn}$ & 800.0 & $3580.0-10069.0$ & 5808.3 & $467.0-24554.0$ & 7032.67 \\
\hline $\mathrm{Ag}$ & 0.07 & $10.0-12.0$ & 10.8 & $5.0-75.0$ & 18.5 \\
\hline $\mathrm{Cu}$ & 48.0 & $120.0-220.0$ & 155.5 & $40.0-2100.0$ & 196.0 \\
\hline B & 100.0 & $40.0-220.0$ & 135.5 & $76.0-500.0$ & 202.4 \\
\hline $\mathrm{V}$ & 130.0 & $21.0-47.0$ & 34.6 & $21.0-95.0$ & 41.8 \\
\hline $\mathrm{Ni}$ & 74.0 & $20.0-35.0$ & 25.1 & $14.0-78.0$ & 36.4 \\
\hline $\mathrm{Cr}$ & 94.0 & $12.0-44.0$ & 21.7 & $14.0-49.0$ & 29.0 \\
\hline $\mathrm{Bi}$ & 0.097 & $0.10-2.5$ & 1.8 & $0.10-105.0$ & 28.0 \\
\hline $\mathrm{Cd}$ & 0.42 & $2.50-3.5$ & 2.8 & $0.1-380.0$ & 23.5 \\
\hline Co & 19.0 & $6.0-19.0$ & 14.6 & $3.0-53.0$ & 16.7 \\
\hline $\mathrm{Ga}$ & 22.0 & $8.0-17.0$ & 11.4 & $5.0-17.0$ & 9.9 \\
\hline $\mathrm{Li}$ & 65.0 & $0.5-30.4$ & 15.1 & $3.9-40.5$ & 28.1 \\
\hline $\mathrm{Be}$ & 0.3 & $0.9-1.3$ & 1.1 & $0.7-1.7$ & 1.2 \\
\hline Sc & 13.0 & $4.6-10.0$ & 7.8 & $3.4-8.9$ & 6.1 \\
\hline $\mathrm{Rb}$ & 150.0 & $61.1-97.0$ & 87.6 & $8.9-98.1$ & 72.1 \\
\hline $\mathrm{Sr}$ & 330.0 & $55.2-106.5$ & 86.7 & $30.2-201.7$ & 54.7 \\
\hline $\mathrm{Y}$ & 30.0 & $8.7-12.5$ & 10.7 & $5.3-80.9$ & 12.7 \\
\hline $\mathrm{Zr}$ & 170.0 & $20.7-33.0$ & 28.9 & $6.4-47.8$ & 37.3 \\
\hline $\mathrm{Nb}$ & 18.0 & $5.8-8.6$ & 6.8 & $0.8-8.1$ & 6.2 \\
\hline Mo & 2.6 & $0.6-0.9$ & 0.7 & $0.6-2.6$ & 1.0 \\
\hline Cs & 6.5 & $7.9-17.3$ & 10.6 & $1.2-17.6$ & 10.5 \\
\hline $\mathrm{Ba}$ & 660.0 & $238.2-360.7$ & 301.3 & $181.7-388.3$ & 257.1 \\
\hline
\end{tabular}

probably the reason of its accumulation in the tailing dumps and insignificant migration in the water under study. Its content in the tailings waters varies from 0.002 to $0.017 \mathrm{mg} / \mathrm{dm}^{3}$, which is insignificantly higher than the Russian permissible level for fishery water bodies $\left(0.01 \mathrm{mg} / \mathrm{dm}^{3}\right)$ [56].

Lead accumulated in significant quantities is a poor migrant. Due to the effectiveness of the sulfide and carbonate barriers, its content in the tailings waters varies within the range from 0.003 to $0.009 \mathrm{mg} / \mathrm{dm}^{3}$ at the permissible level of $0.006 \mathrm{mg} / \mathrm{dm}^{3}$.

At the low $\mathrm{pH}$ and oxidation-reduction potential levels iron is mainly found in the bivalent form, which contributes to the accumulation of its significant concentrations in the water of the "old" tailings. In general, the acidic geochemical 
TABLE 2: The chemical composition of the water in the tailings ponds of KCM.

\begin{tabular}{|c|c|c|c|c|c|c|c|c|}
\hline \multirow[b]{2}{*}{ Components } & \multirow[b]{2}{*}{$\begin{array}{c}\text { Maximum } \\
\text { permissible } \\
\text { concentration }[56]\end{array}$} & \multirow[b]{2}{*}{$\begin{array}{c}\text { Toxicity- } \\
\text { dependant } \\
\text { hazard class }[56]\end{array}$} & \multicolumn{6}{|c|}{ Content, $\mathrm{mg} / \mathrm{dm}^{3}$} \\
\hline & & & $\begin{array}{l}\text { "New" } \\
\text { tailings }\end{array}$ & $\begin{array}{l}\text { “Old” } \\
\text { Pond } 1\end{array}$ & $\begin{array}{l}\text { tailing } \\
\text { Pond } \\
2\end{array}$ & $\begin{array}{l}\text { Rudnaya river, } \\
\text { (background) }\end{array}$ & $\begin{array}{l}\text { Rudnaya river, } \\
\text { point of the } \\
\text { discharge }\end{array}$ & $\begin{array}{c}\text { Rudnaya river, } \\
\text { below the } \\
\text { discharge }\end{array}$ \\
\hline Mineralization & 1000.0 & - & 154.2 & 12807.3 & 6844.6 & 46.6 & 1340.6 & 168.0 \\
\hline $\mathrm{pH}$ & $6.5-8.5$ & - & 7.4 & 2.5 & 2.3 & 6.9 & 4.6 & 6.7 \\
\hline $\mathrm{HCO}_{3}$ & 1000.0 & - & 29.3 & $<0,06$ & $<0,04$ & 18.3 & 8.0 & 23.2 \\
\hline $\mathrm{SO}_{4}$ & 100.0 & - & 78.4 & 9364.0 & 5250.0 & 12.9 & 933.9 & 101.7 \\
\hline $\mathrm{Cl}$ & 300.0 & $4 \mathrm{e}$ & $<0.5$ & $<0.5$ & $<0.5$ & $<0.5$ & $<0.5$ & $<0.5$ \\
\hline $\mathrm{Ca}$ & 180.0 & $4 e$ & 31.8 & 544.0 & 408.1 & 8.7 & 277.1 & 26.9 \\
\hline $\mathrm{Mg}$ & 40.0 & 4 & 7.5 & 216.0 & 248.5 & 1.5 & 105.4 & 9.1 \\
\hline $\mathrm{Na}$ & 120.0 & $4 \mathrm{e}$ & 3.4 & 4.9 & 3.3 & 4.3 & 13.7 & 5.2 \\
\hline $\mathrm{K}$ & 50.0 & $4 \mathrm{e}$ & 1.6 & $<0.01$ & $<0.01$ & 0.4 & 5.6 & 0.8 \\
\hline $\mathrm{Si}$ & - & - & 5.1 & 48.6 & 35.2 & 9.9 & 8.7 & 5.9 \\
\hline $\mathrm{Fe}_{\text {total }}$ & 0.1 & 4 & 1.8 & 2677.0 & 934.5 & 0.05 & 4.4 & 0.7 \\
\hline Oil products & 0.05 & 3 & 0.05 & $<0.05$ & $<0.05$ & $\mathrm{~N} / \mathrm{D}$ & $<0.05$ & $\mathrm{~N} / \mathrm{D}$ \\
\hline $\mathrm{Pb}$ & 0.006 & 2 & 0.0004 & 0.003 & 0.009 & 0.0004 & 0.01 & 0.01 \\
\hline $\mathrm{Zn}$ & 0.01 & 3 & 0.4 & 111.6 & 94.4 & 0.006 & 3.3 & 2.1 \\
\hline $\mathrm{Cu}$ & 0.001 & 3 & 0.001 & 0.3 & 0.2 & 0.0004 & 0.01 & 0.004 \\
\hline $\mathrm{Mn}$ & 0.01 & 4 & 1.7 & 527.5 & 43.4 & 0.008 & 8.3 & 0.98 \\
\hline $\mathrm{Al}$ & 0.04 & 4 & 0.03 & 82.2 & 46.8 & 0.03 & 6.5 & 0.5 \\
\hline $\mathrm{Cd}$ & 0.005 & 2 & 0.001 & 0.04 & 0.04 & 0.00002 & 0.01 & 0.004 \\
\hline As & 0.05 & 3 & 0.006 & 0.2 & 0.05 & 0.001 & 0.004 & 0.001 \\
\hline $\mathrm{Cr}_{\text {total }}$ & 0.02 & 3 & 0.00003 & 0.01 & 0.007 & 0.0002 & 0.002 & 0.0001 \\
\hline $\mathrm{Co}$ & 0.01 & 3 & 0.002 & 0.02 & 0.02 & $\mathrm{~N} / \mathrm{D}$ & 0.02 & $\mathrm{~N} / \mathrm{D}$ \\
\hline $\mathrm{Be}$ & 0.0003 & 2 & 0.00002 & 0.002 & 0.002 & $\mathrm{~N} / \mathrm{D}$ & 0.002 & $\mathrm{~N} / \mathrm{D}$ \\
\hline B & 0.5 & 4 & $<0.01$ & $<0.01$ & $<0.01$ & 0.01 & 0.02 & 0.01 \\
\hline $\mathrm{Sr}$ & 0.4 & 3 & 0.3 & 1.2 & 1.3 & 0.06 & 2.1 & 0.3 \\
\hline $\mathrm{Li}$ & 0.08 & 4 & 0.006 & 0.02 & 0.03 & 0.003 & 0.06 & 0.01 \\
\hline $\mathrm{Ni}$ & 0.01 & 3 & $<\mathrm{LD}$ & 0.05 & 0.06 & 0.0001 & 0.06 & 0.002 \\
\hline Se & 0.002 & 2 & 0.00006 & $<\mathrm{LD}$ & 0.0004 & 0.0002 & 0.01 & 0.0003 \\
\hline $\mathrm{Rb}$ & 0.1 & 4 & 0.001 & 0.0003 & 0.0004 & $\mathrm{~N} / \mathrm{D}$ & 0.003 & $\mathrm{~N} / \mathrm{D}$ \\
\hline Cs & 1.0 & 4 & 0.0001 & 0.0003 & 0.0007 & 0.0005 & 0.0003 & 0.001 \\
\hline $\mathrm{V}$ & 0.001 & 3 & 0.00002 & 0.003 & 0.0001 & $\mathrm{~N} / \mathrm{D}$ & 0.0002 & $\mathrm{~N} / \mathrm{D}$ \\
\hline $\mathrm{Ba}$ & 0.74 & 4 & 0.05 & 1.7 & 0.0004 & 0.006 & 0.02 & 0.01 \\
\hline
\end{tabular}

-, no data; N/D, not detected; $<\mathrm{LD}$, below the level of detection; components exceeding the MPC are in italics.

environment is favorable for transfer to water and accumulation of various elements that concentrate in the rocks of the tailings, which is clearly shown in Table 2.

\subsection{Physical-Chemical Modeling of the Water-Rock-Gas} System. To quantify the patterns of hydrochemical processes in the tailings, we carried out the physical-chemical modeling of the water-rock-gas system.

It is known that primary minerals mineralize the water at the dissolution rate equal to or higher than $10^{-10} \mathrm{~g} / \mathrm{cm}^{2}$. In the studied rocks, the primary minerals are feldspars (albite, orthoclase, and anorthite), calcite, quartz, apatite, pyrite, biotite, sphene etc. [59]. Assuming the mineral dissolution rate is constant with an increase of the reacting rock mass, then, according to B. N. Ryzhenko and S. R. Kraynova $[60,61]$, the rock-water mass ratio $(\mathrm{R} / \mathrm{W})$ takes the meaning of the time of interaction between the rock and water solution. Based on the above, we selected the following $R / \mathrm{W}$ mass ratios for the modeling: 0.0022 (step 1); 0.0035 (step 2); 0.004 (step 3); 0.006 (step 4); 0.013 (step 5); 0.026 (step 6).
The model showed that, even with the shortest contact of 2.2 grams of rock and $1 \mathrm{~kg}$ of water (step 1 of the computational experiment), the mineralization of water reaches $3391.59 \mathrm{mg} / \mathrm{dm}^{3}$. The waters had sulfate anionic and calcium (magnesium-calcium) cationic composition. The hydrogen index $(\mathrm{pH})$ varied within $2.1-2.5$. With the increase of $R / \mathrm{W}$ mass ratio (steps 1 to 6 ), the mineralization of the water solution rises and a characteristic directed change in the composition of the aqueous phase is observed (Figure 3).

The calculations of the electrolytic dissociation in the waters under study indicate that the components migrate both in the form of intrinsic uncomplexed ions and in the form of complex compounds. With an increase in the $R / \mathrm{W}$ mass ratio (the time of interaction) and increase in mineralization, the proportion of complex compounds grows. As a result of this, mainly sulfate complexes are formed in the "old" tailings pond, and hydrocarbonate and carbonate complexes in the "new" tailings pond. An example is presented in Figure 4, showing a decrease in the fraction of uncomplexed ions and an increase in calcium and magnesium complex compounds with rising mineralization of 


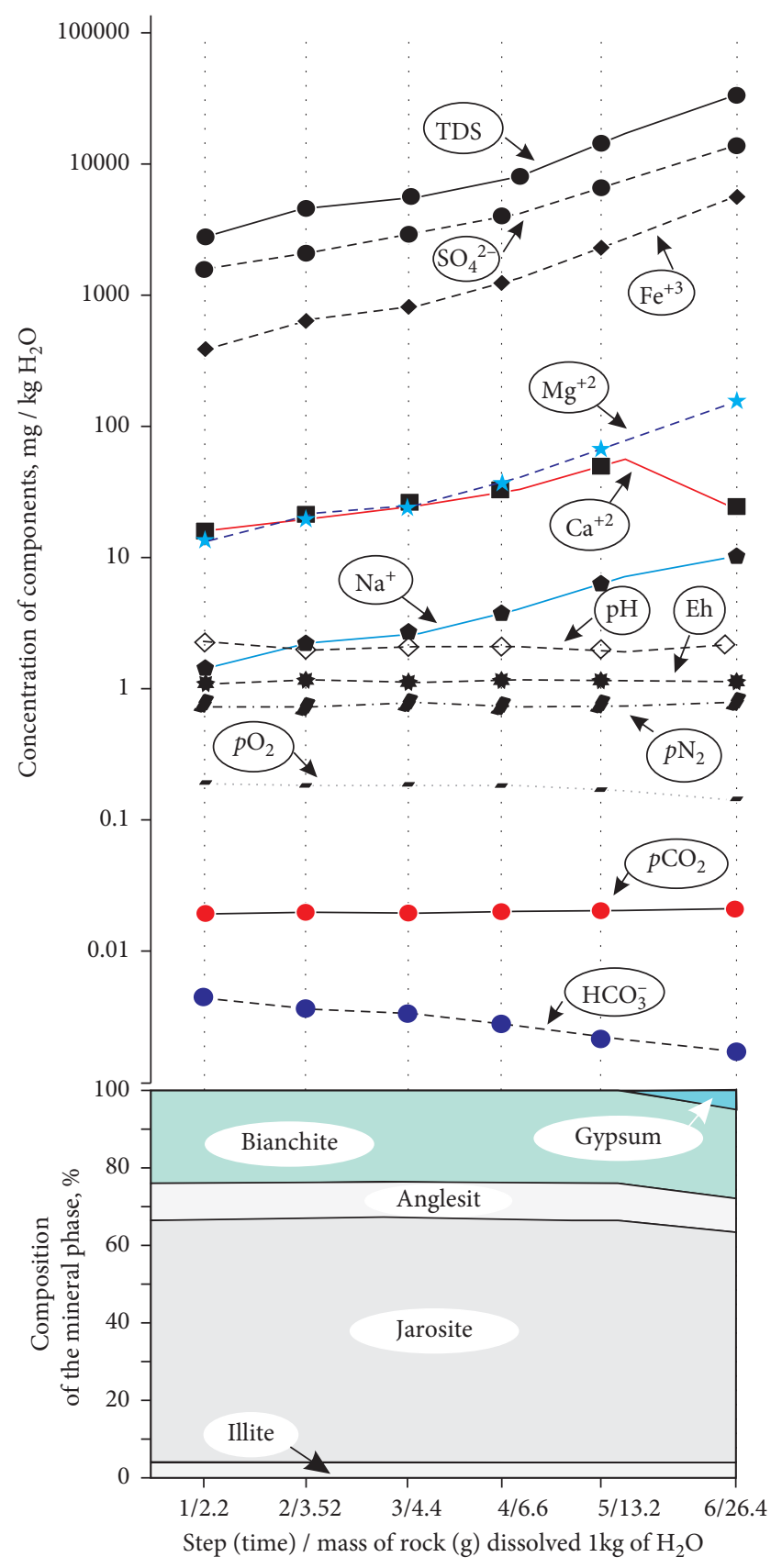

FIGURE 3: The results of modeling of the closed rock-water system evolution $\left(\mathrm{CO}_{2}=0.01 \mathrm{~kg} / \mathrm{L}\right.$ per $1 \mathrm{~kg}$ of $\mathrm{H}_{2} \mathrm{O}$; atmospheric gas $=0.3 \mathrm{~kg} / \mathrm{L}$ per $1 \mathrm{~kg}$ of $\mathrm{H}_{2} \mathrm{O}$ ).

the water in the "old" tailings pond, as well as variations in the behavior of iron ions, probably caused by new of mineral forms.

The most notable changes in the behavior of chemical components in water are inherent to the elements found in the structures of the resulting secondary minerals (Figure 3 ). During the modeling, it was found that, as the solution gets saturated with certain components, the secondary mineral phases are formed (illite-K.064Na.03Al1.83Fe.0, jarosite$\mathrm{KFe}_{3}\left(\mathrm{SO}_{4}\right)_{2}(\mathrm{OH})_{6}$, anglesit- $\mathrm{PbSO}_{4}$, bianchite- $\mathrm{ZnSO}_{4}$. $6 \mathrm{H}_{2} \mathrm{O}$, and gypsum- $\mathrm{CaSO}_{4} \cdot 2 \mathrm{H}_{2} \mathrm{O}$ ).
The obtained results of physicochemical modeling are in good agreement with field observations. The water with the salinity of $>15000 \mathrm{mg} / \mathrm{dm}^{3}$ is supersaturated with calcium ions, which is indicated by gypsum formations $\left(\mathrm{CaSO}_{4} \cdot 2 \mathrm{H}_{2} \mathrm{O}\right)$ identified by mineralogical and the X-ray diffraction study.

The main sources of $\mathrm{Fe}$ in the studied water are iron sulfides and aluminosilicate minerals, mainly hornblendes, pyroxenes, biotite, epidote, etc. As these minerals dissolve, the chemical elements are transferred into the aqueous solution. Iron exists in two oxidation states under the considered conditions $\left(\mathrm{Fe}^{2+}\right.$ and $\left.\mathrm{Fe}^{3+}\right)$ and, as shown in Figure 4, it is transported by the aqueous solution, mainly in the form of $\mathrm{Fe}^{3+}$ ions and $\mathrm{FeOH}^{2+}$ compounds.

3.4. Morphology of Secondary Minerals. Due to the effectiveness of geochemical barriers, as well as evaporation and freezing out, various sulfate mineral forms of iron are formed [62-66]. High $\mathrm{pH}$ and/or redox potential create stable conditions for trivalent iron, which hydrolyzes to form the insoluble iron hydroxide $\left(\mathrm{Fe}(\mathrm{OH})_{3}\right)$. Iron hydroxides, in turn, are a geochemical barrier to arsenic, a very strong toxicant. Iron hydroxides efficiently sorb its migration forms, especially arsenate [17,67-69]. Iron sulfates are a barrier for the reduced As (III), which is described by Ya. E. Yudovich and M. P. Ketris [58] and is clearly traced by us in the study of the mineralogy of the tailings ponds and the microprobe analysis of mineral formations.

Through the example of the study of the micromorphology and composition of a newly formed fibroferrite $\left(\mathrm{Fe}\left(\mathrm{SO}_{4}\right) \cdot(\mathrm{OH}) \cdot 5 \mathrm{H}_{2} \mathrm{O}\right)$ (Figure $\left.5(\mathrm{a})\right)$, identified by the X-ray diffraction method, we showed that it is characterized by the elevated content of arsenic (1.46\%), zinc (1.21\%), manganese (1.66\%), aluminum $(0.89 \%)$, and magnesium $(1.9 \%)$ (Figure 6; Table 3). A characteristic feature of the debyeogram of fibroferrite is the increase of the intensity of some arcs near the equatorial line. Fibroferrite is formed mainly due to the direct oxidation of pyrite, pyrrhotite, and chalcopyrite as a result of exothermic reactions.

In addition, newly formed minerals such as melanterite (Figure 5(b)), ferrohexahydrite, rozenite, copiapite (Figures 5(c) and 5(d)), hydroalumogoethite, and gypsum, found in the tailings under study, control the content in water of such components as $\mathrm{As}, \mathrm{Fe}, \mathrm{Zn}, \mathrm{Ca}, \mathrm{Cu}, \mathrm{Al}, \mathrm{Mg}$, and $\mathrm{Mn}$.

3.5. Effect of Elevated Contents of Heavy Metals on Human Health and Natural Ecosystems. The elements contained in elevated concentrations in the waters of the tailings ponds (Table 2) are classified as priority environmental pollutants in Russia [56].

For example, zinc is among mutagenic, gonadotoxic, and embryotoxic elements. Prolonged exposure (5-20 years) to its compounds leads to gastrointestinal disorders, increase in the number of acute respiratory infections and dental caries, changes in morphological composition of blood, and increase in incidence of illness in children [70]. 


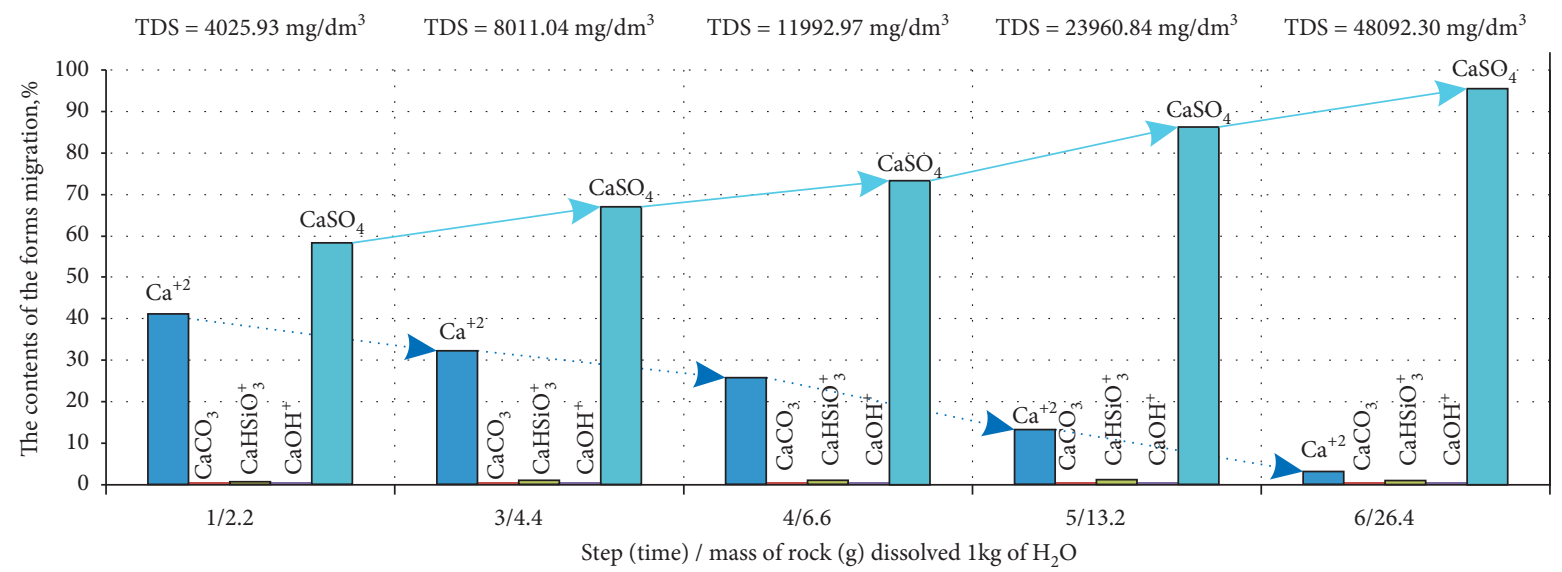

(a)

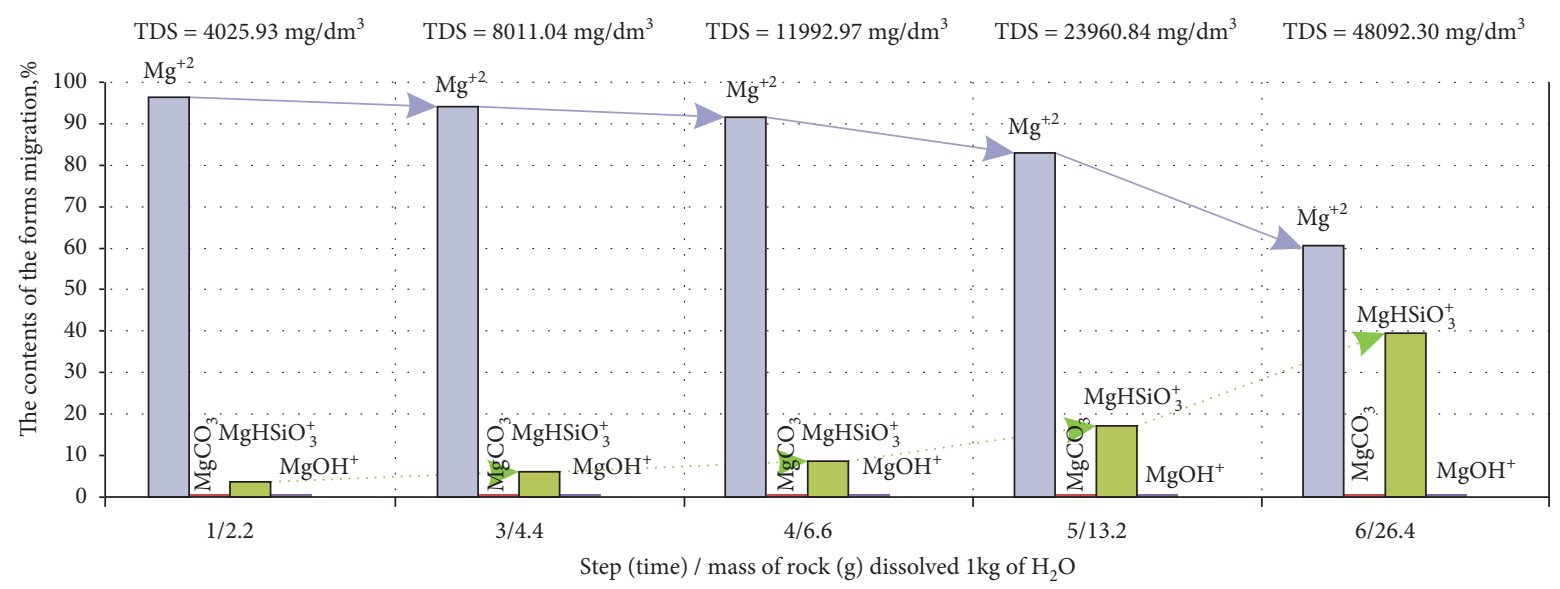

(b)

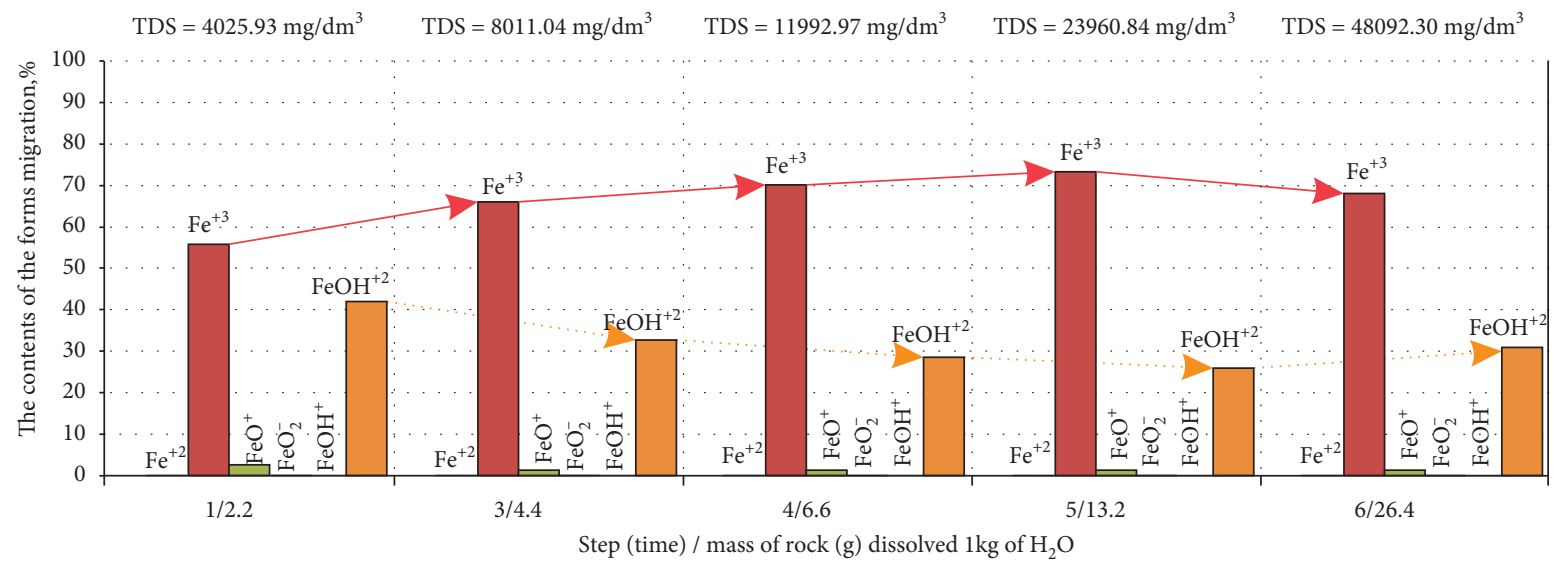

(c)

Figure 4: Inorganic migration of $\mathrm{Ca}(\mathrm{a}), \mathrm{Mg}(\mathrm{b})$, and $\mathrm{Fe}(\mathrm{c})$ in the waters of the "old" tailings pond.

Cadmium is a polytropic poison. Chronic intoxication can lead to anosmia, headaches, nosebleeds, increased mortality in cardiovascular diseases, effects on the gastrointestinal tract, damage to the central and peripheral nervous systems, diseases of the liver, kidneys, skeletal muscles, and bone tissue.

Copper is carcinogenic and gonadotoxic. In compounds, it irritates the mucous membranes of the upper respiratory tract and the gastrointestinal tract. In chronic intoxication, it causes functional disorders of the nervous system and impaired renal function and liver.

Lead is a polytropic poison that causes pathological changes in the nervous system, blood, and blood vessels. It causes lung disease in children. Inorganic lead compounds $\left(\mathrm{Pb}^{2+}\right)$ disrupt the body's metabolism and are inhibitors of blood and tissue enzymes. Lead can enhance the 


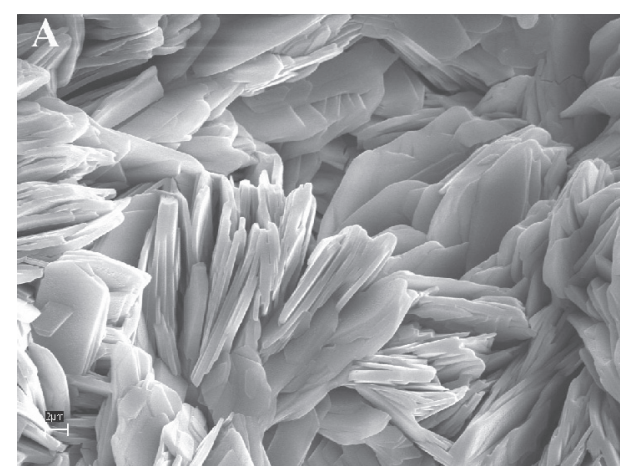

(a)

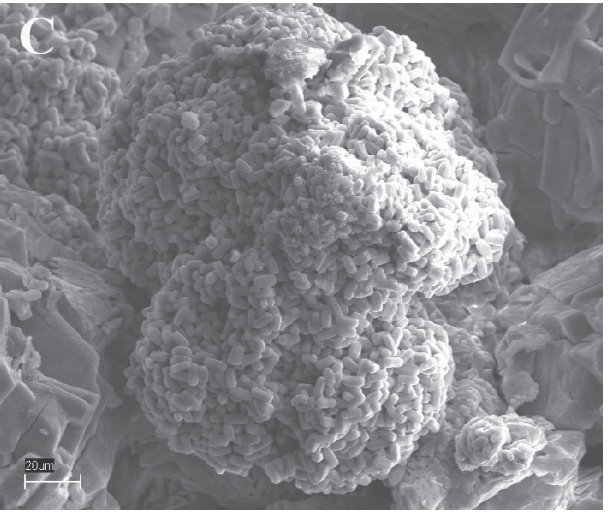

(c)

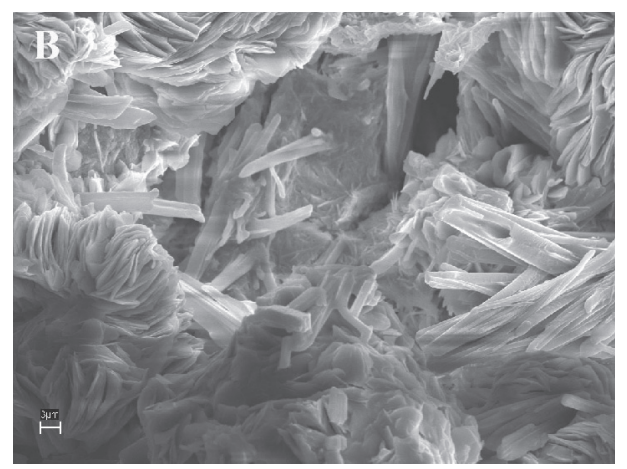

(b)

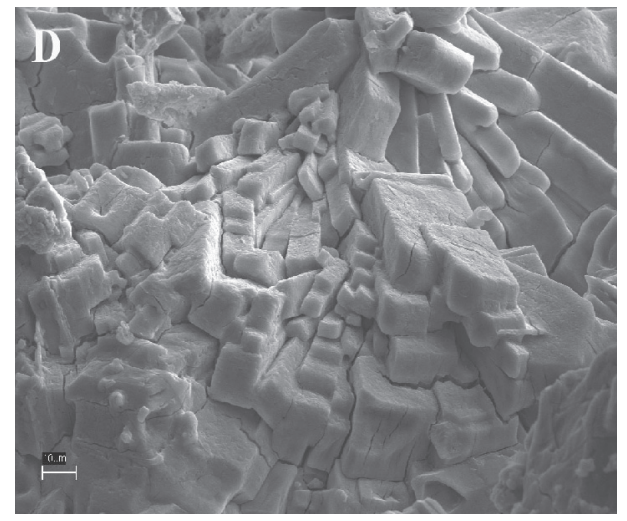

(d)

Figure 5: The morphology of sulfates formed in the tailings: (a) laminal fibroferrite, (b) sheaf-like melanterite, (c) hexagonal prisms of copiapite with a truncated bipyramidal tail, and (d) tetragonal prisms of copiapite. Microscopes JSM-6490LV and ZEISS EVO 50XVP.

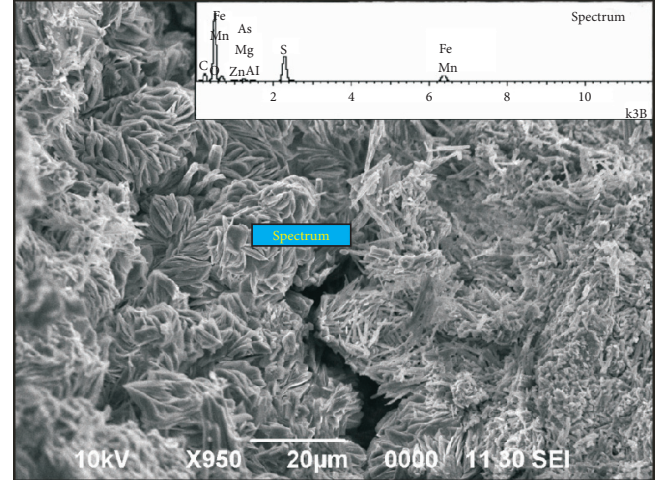

FIGURE 6: The morphology and composition of fibroferrite (microscope ZEISS EVO 50XVP).

development of diseases of the anemia group. Diseases of the peripheral nervous system (cephalgia, ischialgia, and myoneuralgia) are associated with an excess of lead in soils and waters. Lead accumulates in bones, hair, tissues of the aorta, liver, and kidneys, causing paralysis of the nervous system, anemia, and intestinal spasms. In areas near polymetallic mines, there is often a direct correlation between the distribution of lead in soils and the incidence of atherosclerosis and caries [4].

Arsenic and its compounds are highly toxic. First of all, they affect the nervous system vascular walls, increase the
TABLE 3: Chemical composition of fibroferrite

\begin{tabular}{lcccc}
\hline \multirow{2}{*}{ Element } & \multirow{2}{*}{ Weight (\%) } & \multirow{2}{*}{ Atomic (\%) } & \multicolumn{2}{c}{ Oxide form } \\
& & & Formula & Mass (\%) \\
\hline $\mathrm{Mg}$ & 1.90 & 1.84 & $\mathrm{MgO}^{2}$ & 3.14 \\
$\mathrm{Al}$ & 0.89 & 0.78 & $\mathrm{Al}_{2} \mathrm{O}_{3}$ & 1.68 \\
$\mathrm{~S}$ & 24.72 & 18.16 & $\mathrm{SO}_{3}$ & 61.72 \\
$\mathrm{Mn}$ & 1.66 & 0.71 & $\mathrm{MnO}$ & 2.14 \\
$\mathrm{Fe}$ & 21.68 & 9.15 & $\mathrm{FeO}$ & 27.89 \\
$\mathrm{Zn}$ & 1.21 & 0.44 & $\mathrm{ZnO}$ & 1.51 \\
$\mathrm{As}$ & 1.46 & 0.46 & $\mathrm{As}_{2} \mathrm{O}_{3}$ & 1.92 \\
$\mathrm{O}$ & 46.49 & 68.47 & & \\
Total & 100.00 & & & 100.00 \\
\hline
\end{tabular}

permeability and paralysis of capillaries, and develop the necrobiotic lesions in the liver, kidneys, heart, and intestines [4]. In addition, they cause disorders of fat and hydrocarbon metabolism, dermatitis in children, and skin cancer. High concentrations of arsenic in the soil lead to plant death.

Water-soluble toxic salts, which include components such as $\mathrm{CO}_{3}{ }^{2-}, \mathrm{HCO}_{3}{ }^{-}, \mathrm{Cl}^{-}, \mathrm{SO}_{4}{ }^{2-}, \mathrm{Ca}^{2+}, \mathrm{Mg}^{2+}$, and $\mathrm{Na}^{+}$in various concentrations, inhibit the growth and development of plants.

3.6. Impact on the Local Rudnaya River. The drainage from the "old" tailings pond exudes through the dam and flows into the Rudnaya river (Figure 7). This river is the largest 


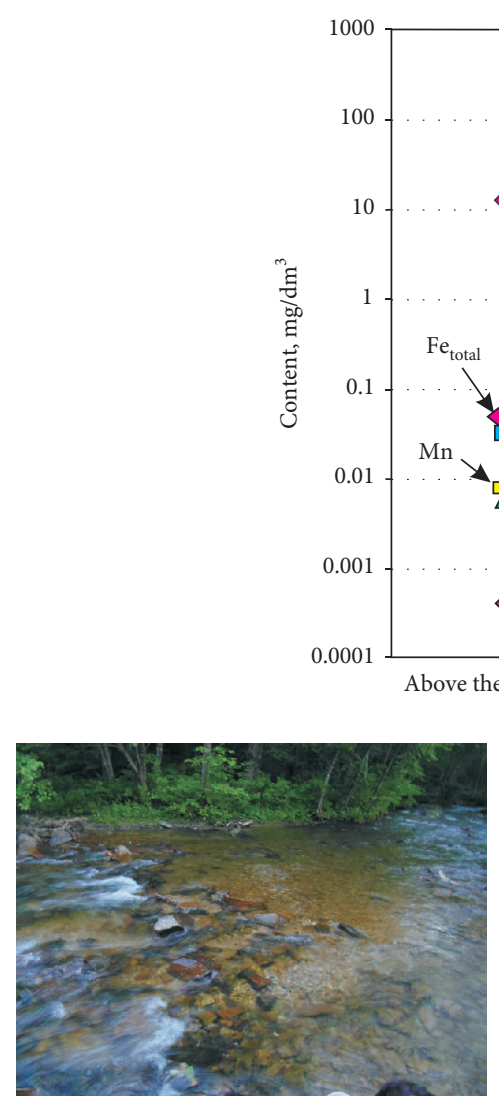

(A)

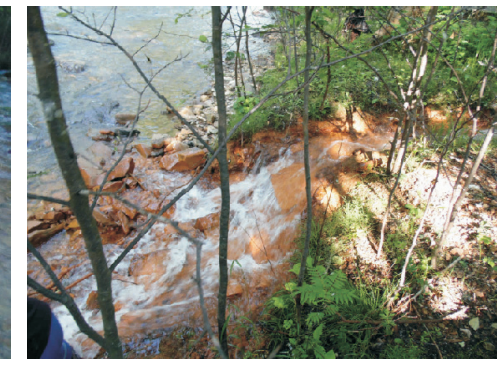

(B)

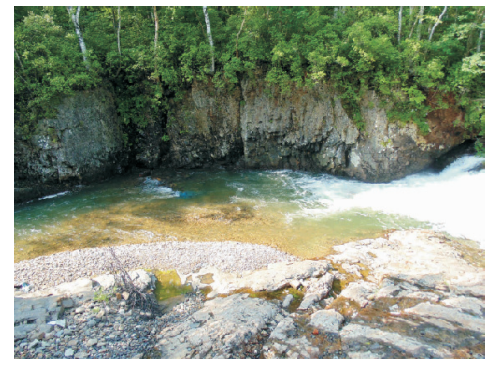

(C)

FIGURE 7: The diagram of changes in the content of iron, zinc, manganese, copper, aluminum, and sulfate anion in the Rudnaya river under the influence of the drainage from the "old" tailings pond of KCM: (a) Rudnaya river above the discharge; (b) point of discharge; (c) below the discharge.

waterway in the area. It flows from the Northwest to the Southeast from the watershed of the Sikhote-Alin ridge and into the Rudnaya Pristan bay. The length of the river is $73 \mathrm{~km}$, the catchment area is $1140 \mathrm{~km}^{2}$ with an average height of $395 \mathrm{~m}$, the total fall of stream is $942 \mathrm{~m}$, and the average slope is $12.9 \%$. The average flow width varies from $3.5 \mathrm{~m}$ (in winter) to $11.5 \mathrm{~m}$ (in summer), the average depth is from 0.15 to $0.34 \mathrm{~m}$, and the average speed is from 0.13 to $0.19 \mathrm{mps}$.

The waters of the river in the upper reach (background) are fresh (mineralization $46.58 \mathrm{mg} / \mathrm{dm}^{3}$ ) bicarbonate calcium (Table 2). The content of all the components is normal and does not exceed the maximum permissible concentrations [56].

The analysis of the impact of the water from the "old" tailings pond of KCM on the composition of water in the Rudnaya river showed that the water flowing from the tailings triples the total mineralization of the watercourse relative to the background values (Table 2), saturating the waters of the river with $\mathrm{SO}_{4}\left(933.9 \mathrm{mg} / \mathrm{dm}^{3}\right), \mathrm{Ca}(277.1 \mathrm{mg} /$ $\left.\mathrm{dm}^{3}\right), \quad \mathrm{Mg}\left(105.4 \mathrm{mg} / \mathrm{dm}^{3}\right), \quad \mathrm{Fe}_{\text {total }}\left(4.39 \mathrm{mg} / \mathrm{dm}^{3}\right), \quad \mathrm{Pb}$ $\left(0.01 \mathrm{mg} / \mathrm{dm}^{3}\right), \mathrm{Zn}\left(3.31 \mathrm{mg} / \mathrm{dm}^{3}\right), \mathrm{Cu}\left(0.014 \mathrm{mg} / \mathrm{dm}^{3}\right), \mathrm{Mn}$ $\left(8.33 \mathrm{mg} / \mathrm{dm}^{3}\right), \mathrm{Al}\left(6.48 \mathrm{mg} / \mathrm{dm}^{3}\right), \mathrm{Cd}\left(0.01 \mathrm{mg} / \mathrm{dm}^{3}\right)$, Co $\left(0.023 \mathrm{mg} / \mathrm{dm}^{3}\right), \operatorname{Be}\left(0.002 \mathrm{mg} / \mathrm{dm}^{3}\right), \mathrm{Sr}\left(2.08 \mathrm{mg} / \mathrm{dm}^{3}\right)$, and $\mathrm{Ni}\left(0.062 \mathrm{mg} / \mathrm{dm}^{3}\right)$. The $\mathrm{pH}$ of the river's water at the discharge point is 4.61 . However, the negative impact is of a local nature, probably due to the substantial volume of the river in the year of sampling (2015). Already $500 \mathrm{~m}$ downstream the concentration of many of the above elements is reduced to safe permissible levels. The maximum permissible concentrations are exceeded only for $\mathrm{SO}_{4}$ $\left(101.73 \mathrm{mg} / \mathrm{dm}^{3}\right), F e_{\text {total }}\left(0.73 \mathrm{mg} / \mathrm{dm}^{3}\right), \mathrm{Zn}\left(2.08 \mathrm{mg} / \mathrm{dm}^{3}\right)$, $\mathrm{Cu}\left(0.004 \mathrm{mg} / \mathrm{dm}^{3}\right), \mathrm{Mn}\left(0.98 \mathrm{mg} / \mathrm{dm}^{3}\right), \mathrm{Al}\left(0.49 \mathrm{mg} / \mathrm{dm}^{3}\right)$, and $\mathrm{Sr}\left(0.27 \mathrm{mg} / \mathrm{dm}^{3}\right)$ (Table 2; Figure 7).

Apparently, the mineralization of the river water depends, inter alia, on the volume of the river in the study period. For instance, according to the data from 2004 [71], the concentrations of metals decreased insignificantly downstream from the discharge point and a small amount of clean water inflow did not contribute to a noticeable dilution of contaminated water. The mineralized waters of the Rudnaya river retain abnormally high concentrations of sulfates and $\mathrm{Zn}, \mathrm{Cd}$, and As at a considerable distance from the influx of acid rock drainage.

\section{Conclusions}

In this study, we explored the physical and chemical processes that lead to the formation of acid tailings drainage and its impact on the river water. Based on the geochemical studies and the results of physicochemical modeling, we showed that the geochemical specificity of the tailings 
drainage is formed in the catchment area and transformed in the direction of the filtration flow. Geochemical features are determined by the ratio of interacting masses of rock, water, and gas. Secondary minerals as cementing phases and surface formations control the content of elements in the water.

In the study area, the minerals and rocks undergo changes that lead to the formation of highly mineralized (mineralization $6844.6-12807.3 \mathrm{mg} / \mathrm{dm}^{3}$ and more), acidic ( $\mathrm{pH} 2.3-2.5)$ waters saturated with various elements. The maximum permissible concentrations were exceeded for $\mathrm{Zn}$, $\mathrm{Cd}, \mathrm{Cu}, \mathrm{Mg}, \mathrm{Fe}_{\text {total }}, \mathrm{Pb}, \mathrm{Mn}, \mathrm{Al}, \mathrm{As}, \mathrm{Co}, \mathrm{Be}, \mathrm{Sr}, \mathrm{Ni}$, and $\mathrm{Ba}$. The tailings are the sources of pollution of the human environment and natural ecosystems with heavy metals.

However, the intoxication of the ecosystem by tailing products is partially inhibited by the secondary minerals in the tailings. Nevertheless, the assessment of the impact of the water of the "old" tailings pond of KCM on the composition of water in the Rudnaya river showed that the drainage from the tailings pond triples the total mineralization of the watercourse relative to the background values, saturating the waters of the river with $\mathrm{SO}_{4}, \mathrm{Ca}, \mathrm{Mg}, \mathrm{Fe}, \mathrm{Pb}, \mathrm{Zn}, \mathrm{Cu}, \mathrm{Mn}, \mathrm{Al}$, $\mathrm{Cd}, \mathrm{Co}, \mathrm{Be}, \mathrm{Sr}$, and Ni. Still, the negative impact is of a local nature, and already $500 \mathrm{~m}$ downstream the concentration of many of the above elements is reduced.

The system that forms the chemical composition of highly mineralized waters in the tailings ponds under study is far from the equilibrium state. The oxidation of sulfides and dissolution of other hypogene minerals and rocks, as well as the migration of oxidation and hydrolysis products, will continue indefinitely affecting the environment.

In this regard, it is necessary to conduct environmental monitoring and undertake activities aimed at the recovery of mature concentration tailings or at suppressing the activity of hazardous elements by the conservation of tailings ponds.

\section{Data Availability}

The data used for the study are presented within this paper.

\section{Conflicts of Interest}

The authors declare that there are no conflicts of interest regarding the publication of this paper.

\section{Acknowledgments}

The authors would like to thank Dr. Muhammad Amjad Nawaz from Education and Scientific Center of Nanotechnology, Far Eastern Federal University (Vladivostok, Russian Federation), for his help in copy editing the manuscript and correcting the English language.

\section{References}

[1] D. W. Blowes and J. L. Jambor, "The pore-water geochemistry and the mineralogy of the vadose zone of sulfide tailings, Waite Amulet, Quebec, Canada," Applied Geochemistry, vol. 5, no. 3, pp. 327-346, 1990.
[2] D. W. Blowes, E. J. Reardon, and J. L. Jambor, "The formation and potential importance of cemented layers in inactive sulfide mine tailings) The formation and potential importance of cemented layers in inactive sulphide mine tailings," Geochimica et Cosmochimica Acta, vol. 55, no. 4, pp. 965-978, 1991.

[3] R. H. Cherry, D. W. Blowes, W. D. Robertson, and J. L. Jambor, "The hydrogeochemistry of the Nickel Rim mine tailings impoundment, Sudbury, Ontario," Journal of Contaminant Hydrology, vol. 41, no. 1-2, pp. 49-80, 2000.

[4] I. A. Tarasenko and A. V. Zin'kov, Ecological Consequences of the Mineralogical-Geochemical Transformations of the Concentration Tailings of $\mathrm{Sn}-\mathrm{Ag}-\mathrm{Pb}-\mathrm{Zn}$ Ores (Primorye, Dalnegorsky District), Dalnauka, Vladivostok, Russia, 2001, (In Russian).

[5] B. Dold and L. Fontboté, "A mineralogical and geochemical study of element mobility in sulfide mine tailings of Fe oxide $\mathrm{Cu}-\mathrm{Au}$ deposits from the Punta del Cobre belt, northern Chile," Chemical Geology, vol. 189, no. 3-4, pp. 135-163, 2002.

[6] M. C. Moncur, C. J. Ptacek, D. W. Blowes, and J. L. Jambor, "Release, transport and attenuation of metals from an old tailings impoundment," Applied Geochemistry, vol. 20, no. 3, pp. 639-659, 2005.

[7] A. Chen, C. Lin, W. Lu et al., "Well water contaminated by acidic mine water from the Dabaoshan Mine, South China: chemistry and toxicity," Chemosphere, vol. 70, no. 2, pp. 248-255, 2007.

[8] R. A. Wuana and F. E. Okieimen, "Heavy metals in contaminated soils: a review of sources, chemistry, risks and best available strategies for remediation," ISRN Ecol, p. 402647, 2011.

[9] M. N. Bezrodnova and I. A. Tarasenko, "On the action of the stale tailings of the processing plant Sinanchaolovo on the environment," The Far Eastern Federal University: School of Engineering Bulletin, vol. 3, no. 16, pp. 60-65, 2013, (In Russian).

[10] N. V. Yurkevich, O. P. Saeva, and N. A. Pal'chik, "Arsenic mobility in two mine tailings drainage systems and its removal from solution by natural geochemical barriers," Applied Geochemistry, vol. 27, no. 11, pp. 2260-2270, 2012.

[11] N. V. Yurkevich, N. A. Abrosimova, S. B. Bortnikova, Y. G. Karin, and O. P. Saeva, "Geophysical investigations for evaluation of environmental pollution in a mine tailings area," Toxicological \& Environmental Chemistry, vol. 99, no. 9-10, pp. 1328-1345, 2017.

[12] L. Angelovičová and D. Fazekašová, "Contamination of the soil and water environment by heavy metals in the former mining area of Rudňany (slovakia)," Soil and Water Research, vol. 9, pp. 18-24, 2014.

[13] N. I. Grehnev, "Mining enterprises wastes that create economic and ecologic problems to subsoil usage in the Russian Far Eastern region," Min Inf Anal Bull, vol. 7, pp. 337-343, 2014, (In Russian).

[14] M. Khorasanipour and A. Eslami, "Hydrogeochemistry and contamination of trace elements in $\mathrm{Cu}$-porphyry mine tailings: a case study from the Sarcheshmeh mine, SE Iran," Mine Water and the Environment, vol. 33, no. 4, pp. 335-352, 2014.

[15] D. K. Nordstrom, D. W. Blowes, and C. J. Ptacek, "Hydrogeochemistry and microbiology of mine drainage," Applied Geochemistry, vol. 57, pp. 3-16, 2015.

[16] M. B. J. Lindsay, M. C. Moncur, J. G. Bain, J. L. Jambor, C. J. Ptacek, and D. W. Blowes, "Geochemical and mineralogical aspects of sulfide mine tailings," Applied Geochemistry, vol. 57, pp. 157-177, 2015. 
[17] H. E. Jamieson, S. R. Walker, and M. B. Parsons, "Mineralogical characterization of mine waste," Applied Geochemistry, vol. 57, pp. 85-105, 2015.

[18] E. S. Saglam and M. Akcay, "Chemical and mineralogical changes of waste and tailings from the Murgul $\mathrm{Cu}$ deposit (Artvin, NE Turkey): implications for occurrence of acid mine drainage," Environmental Science and Pollution Research, vol. 23, no. 7, pp. 6584-6607, 2016.

[19] I. A. Tarasenko, N. A. Kharitonova, A. V. Zin'kov, E. V. Ovodova, and A. V. Korzun, "Tailing dumps at the Krasnorechenskaya concentration mill (Primorskii krai, Russia): geochemistry and mineralogy," Moscow University Geology Bulletin, vol. 72, no. 3, pp. 192-199, 2017.

[20] M. I. Epov, N. V. Yurkevich, S. B. Bortnikova, Y. G. Karin, and O. P. Saeva, "Analysis of mine waste by geocheimical and geophysical methods (a case study of the mine tailing dump of the Salair ore-processing plant)," Russian Geology and Geophysics, vol. 58, no. 12, pp. 1543-1552, 2017.

[21] M. V. Kirillov, S. B. Bortnikova, O. L. Gaskova, and E. P. Shevko, "Authigenic gold in stale tailings of cyanide leaching of gold-sulfide-quartz ores (Komsomol'skii GoldExtracting Factory," Doklady Earth Sciences, vol. 481, no. 2, pp. 1091-1094, 2018.

[22] P. V. Elpatievsky, "Hydrochemical streams produced by sulfidized technogenic lithoaccumulation," Geografiya I Prirodnyye Resursy, vol. 2, pp. 26-34, 2003, (In Russian).

[23] P. L. Younger and C. Wolkersdorfer, "Mining impacts on the fresh water environment: Technical and managerial guidelines for catchment scale management," Mine Water Environ, vol. 23, no. S1, pp. 2-80, 2004.

[24] V. Chudaeva, O. Chudaev, K. Sugimori, M. Matsuo, and A. Kuno, "Aquatic chemistry of the Rudnaja River affected by mine tailings and processing plants," Chinese Journal of Geochemistry, vol. 25, no. S1, p. 150, 2006.

[25] L. Meunier, S. R. Walker, J. Wragg et al., "Effects of soil composition and mineralogy on the bioaccessibility of arsenic from tailings and soil in gold mine districts of Nova Scotia," Environmental Science \& Technology, vol. 44, no. 7, pp. 2667-2674, 2010.

[26] A. M. Sarmiento, A. DelValls, J. M. Nieto, M. J. Salamanca, and M. A. Caraballo, "Toxicity and potential risk assessment of a river polluted by acid mine drainage in the iberian pyrite belt (SW spain)," Science of The Total Environment, vol. 409, no. 22, pp. 4763-4771, 2011.

[27] X. Tao, P. Wu, C. Tang, H. Liu, and J. Sun, "Effect of acid mine drainage on a karst basin: a case study on the high-As coal mining area in Guizhou province, China," Environmental Earth Sciences, vol. 65, no. 3, pp. 631-638, 2012.

[28] V. Hatje, R. M. A. Pedreira, C. E de Rezende et al., "The environmental impacts of one of the largest tailing dam failures worldwide," Scientific Reports, vol. 7, Article ID 10706, 2017.

[29] B. G. Lottermoser, Environmental Indicators in Metal Mining, p. 417, Springer, Basel, Switzerland, 2017.

[30] S. B. Bortnikova, N. V. Silantyeva, A. A. Zapolsky et al., "Assessment of acid base accounting of mine waste rocks and mobility of potentially toxic elements of the Razdolinsky ore field (Krasnoyarsk Territory)," Geo Assets Engineering, vol. 329, no. 12, pp. 55-72, 2018, (In Russian).

[31] B. G. Lottermoser, Mine Wastes: Characterization, Treatment and Environmental Impacts, Springer, Berlin, Heidelberg, 2010.
[32] V. I. Petukhov, E. Gidarakos, A. N Erekhinsky et al., Integrated Sustainable Waste Management: Mining, The Russian Academy of Natural History, Moscow, Russia, 2016.

[33] I. A. Tarasenko, "The involvement of tailings of enrichment plants in the economy is one of the conditions for the environmentally safe development of the region," in Fundamental'nyye Problemy Okhrany Okruzhayushchey Sredy, pp. 20-24, Publishing House of Far Eastern University, 1997Publishing House of Far Eastern University, Vladivostok, Russia, (In Russian).

[34] I. V. Kuznetsova, P. P. Safronov, and N. V. Moiseenko, "Matter-mineral characteristics of technogene placers-potential sources of precious metals (on the example of the Nizhneselemdzhinsky gold-bearing node of Priamurye, Russia)," Georesursy, vol. 21, no. 1, pp. 2-14, 2019.

[35] I. A. Tarasenko, N. A. Kharitonova, E. V. Ovodova, A. V. Zin'kov, and A. V. Korzun, "Transformation of mineralogical and geochemical composition of tails and its influence on the high mineralization water origination (Primorye region, Russia)," Tikhookeanskaya Geologiya, vol. 36, no. 2, pp. 106-118, 2017a, (In Russian).

[36] H. A. Schroeder, J. J. Balassa, and I. H. Tipton, “Abnormal trace metals in man: Tin," Journal of Chronic Diseases, vol. 17, no. 6, pp. 483-502, 1964.

[37] L. Fanfani, "Geochemical studies in area contaminated by abandoned mine tailings," in Water-rock Interaction, Y. K. Kharaka and O. V. Chudaev, Eds., Balkema, Vladivostok, Russia, pp. 875-878, 1995.

[38] I. A. Tarasenko, A. V. Zinkov, E. V. Ovodova, V. I. Petukhov, and I. V. Solyanik, "Geochemistry and mineralogy of old concentration tailings (Dal'negorsky ore district, Primorsky Krai, Russia)," IOP Conference Series: Earth and Environmental Science, vol. 87, no. 4, Article ID 042023, 2017c.

[39] E. A. Radkevich, "Tin ore formations and their practical significance," Sovetskaya Geologiya, vol. 1, pp. 14-24, 1968, (In Russian).

[40] G. P. Vasilenko, Mineralogical and Geochemical Features of Cassiterite-Sulfide Mineralization of the Smirnovskoe Deposit (Primorye), Dissertation, Far East Geological Institute, FarEastern Branch of Russian Academy of Sciences, Vladivostok, Russia, 1970, (In Russian).

[41] V. T. Kazachenko and V. I. Sapin, Manganese Mineralization in Ore Deposits of the East of the USSR, DVO AN SSSR, Vladivostok, Russia, 1987, (In Russian).

[42] N. V. Bulavko, Mineralogy of Skarn Deposits of the Dalnegorsky Ore Field (Primorye), Dal'nevostochnoye knizhnoye izdatel'stvo, Vladivostok, Russia, 2000, (In Russian).

[43] 17.1.5.04-80 GOST, "Non-ferrous metal ores and concentrates," Methods of Sampling and Sample Preparation for Chemical Analysis and Determination of Moisture. Reprint with Changes, Standartinform, Moscow, Russia, 2010, (In Russian).

[44] NSAM No. 499-AES, Determination of the Elemental Composition of Rocks, Soils and Bottom Sediments by Atomic Emission Spectrometry with Inductively Coupled Plasma and Mass Spectrometry with Inductively Coupled Plasma, VIMS, Moscow, Russia, 2015, (In Russian).

[45] K. V. Chudnenko and I. K. Karpov, Selector-Windows, a Software Tool for Calculating Chemical Equilibria Minimizing Thermodynamic Potentials", p. 90, Software Manual, Irkutsk, RussiaSoftware Manual, 2003, (In Russian).

[46] J. L. Haas, G. R. Robinson, and B. S. Hemingway, "Thermodynamic tabulations for selected phases in the system $\mathrm{CaO}-\mathrm{Al}_{2} \mathrm{O}_{3}-\mathrm{SiO}_{2}-\mathrm{H}_{2} \mathrm{O}$ at $101.325 \mathrm{kPa}$ (1 atm) between 273.15 
and $1800 \mathrm{~K}$," Journal of Physical and Chemical Reference Data, vol. 10, no. 3, pp. 575-669, 1981.

[47] E. L. Shock and H. C. Helgeson, "Calculation of the thermodynamic and transport properties of aqueous species at high pressures and temperatures: Correlation algorithms for ionic species and equation of state predictions to $5 \mathrm{~Kb}$ and $1000^{\circ} \mathrm{C}$," Geochimica et Cosmochimica Acta, vol. 52, pp. 2009-2036, 1988.

[48] E. L. Shock, E. H. Oelkers, J. W. Johnson, D. A. Sverjensky, and H. C. Helgeson, "Calculation of the thermodynamic properties of aqueous species at high pressures and temperatures. Effective electrostatic radii, dissociation constants and standard partial molal properties to $1000^{\circ} \mathrm{C}$ and $5 \mathrm{kbar}$," Journal of the Chemical Society, Faraday Transactions, vol. 88, no. 6, pp. 803-826, 1992.

[49] E. L. Shock, "Organic acids in hydrothermal solutions; standard molal thermodynamic properties of carboxylic acids and estimates of dissociation constants at high temperatures and pressures," American Journal of Science, vol. 295, no. 5, pp. 496-580, 1995.

[50] E. L. Shock and C. M. Koretsky, "Metal-organic complexes in geochemical processes: Estimation of standard partial molal thermodynamic properties of aqueous complexes between metal cations and monovalent organic acid ligands at high pressures and temperatures," Geochimica et Cosmochimica Acta, vol. 59, no. 8, pp. 1497-1532, 1995.

[51] E. L. Shock, D. C. Sassani, M. Willis, and D. A. Sverjensky, "Inorganic species in geologic fluids: Correlations among standard molal thermodynamic properties of aqueous ions and hydroxide complexes," Geochimica et Cosmochimica Acta, vol. 61, no. 5, pp. 907-950, 1997.

[52] R. C. Reid, J. M. Prausnitz, and T. K. Sherwood, The Properties of Gases and Liquids, McGraw-Hill Book Company, New York, NY, USA, Third edition, 1977.

[53] R. A. Robie and B. S. Hemingway, "Thermodynamic properties of minerals and related substances at $298.15 \mathrm{~K}$ and 1 bar (105 Pascals) pressure and at higher temperatures," US Geological Survey Circular, vol. 2131, p. 461, 1995.

[54] H. Yokokawa, "Tables of thermodynamic properties of inorganic compounds," J. Nat. Chem. Lab. Industry, vol. 83, pp. 27-121, 1988.

[55] E. V. Sklyarov, Interpretation of Geochemical Data: Textbook, Intermet Engineering, Moscow, Russia, 2001.

[56] List of fishery standards, Maximum Permissible Concentrations (MPCs) and Safe Reference Levels of Impact (OBUV) of Hazardous Substances for Water Bodies of Fishery Importance, p. 304, Izdatel'stvo VNIRO, Moscow, Russia, 1999.

[57] 2.1.4.1074-01 SanPiN, Drinking Water. Hygienic Requirements for Water Quality of Centralized Drinking Water Supply Systems. Quality Control, Federal'nyy tsentr gossanepidnadzora Minzdrava Rossii, Moscow, Russia, 2001.

[58] Y. E. Yudovich and M. P. Ketris, Toxic Trace Elements in Coal, Ural Branch of Russian Academy of Sciences, Ekaterinburg, Russia, 2005.

[59] B. N. Ryzhenko, V. L. Barsukov, and S. N. Knyazeva, "Chemical characteristics (composition, $\mathrm{pH}, \mathrm{Eh}$ ) of rockwater systems," Geokhimiya, no. 6, pp. 618-642, 2000, (In Russian).

[60] B. N. Ryzhenko and S. R. Krainov, "Interactions in a thermodynamically closed rock-water system are the key to the formation of chloride groundwater//Geokhimiya," vol. 10, pp. 1052-1082, 2001, (In Russian).
[61] B. N. Ryzhenko and C.P. Krainov, "Physicochemical factors in the formation of the chemical composition of water in the hypergene zone," Geokhimiya, no. 8, p. 28, 2002, (In Russian).

[62] R. G. Burns and V. M. Burns, "Manganese oxides," in Reviews in Mineralogy: Vol 6. Marine Minerals, R. G. Burns, Ed., pp. 1-46, Mineralogical Society of America, Washington, DC, USA, 1979.

[63] P. Bayliss, "Mineral nomenclature: scapolite," Mineralogical Magazine, vol. 51, no. 359, p. 176, 1987.

[64] C. Sabelli and A. Santucci, "Rare sulfate minerals from the Cetine mine, Tuscany, Italy," Neues Jahrb Miner Monatsh, vol. 4, pp. 171-182, 1987.

[65] R. G. Wiese Jr, M. A. Powell, and W. S. Fyfe, "Spontaneous formation of hydrated iron sulfates on laboratory samples of pyrite- and marcasite-bearing coals," Chemical Geology, vol. 63, no. 1-2, pp. 29-38, 1987.

[66] I. A. Tarasenko, A. V. Zin'kov, and N. A. Nagornova, "Epigenesis of technogenic deposits of the Primorsky Krai," in Proceedings of the Science Technology Conference of "Vologdinskiye Chteniya", Publishing House of the Far Eastern State Technical University, pp. 53-57, Publishing House of the Far Eastern State Technical University, 2009, (In Russian).

[67] P. V. Elpatievsky and L. T. Kovekovdova, "Arsenic in technogenic and natural-technogenic components of the Rudnaya river valley (Primorsky Region)," Vestnik of the Far East Branch of the Russian Academy of Sciences, vol. 5, pp. 78-86, 2001, (In Russian).

[68] V. A. Chudaeva and O. V. Chudaev, "Arsenic in the waters of the Far East," Vestnik of the Far East Branch of the Russian Academy of Sciences, vol. 4, pp. 37-46, 2008, (In Russian).

[69] M. C. Corriveau, H. E. Jamieson, M. B. Parsons, J. L. Campbell, and A. Lanzirotti, "Direct characterization of airborne particles associated with arsenic-rich mine tailings: Particle size, mineralogy and texture," Applied Geochemistry, vol. 26, no. 9-10, pp. 1639-1648, 2011.

[70] E. F. Emlyn, Technogenesis of Pyrite Deposits of the Urals, Izdatel'stvo Ural'skogo Universiteta, Sverdlovsk, 1991, (In Russian).

[71] V. S. Arzhanova, "The influence of mining technogenesis on river waters," vol. 1, Geografiya i Prirodnye Resursy, pp. 39-44, Geografiya i Prirodnye Resursy, 2010, (In Russian). 